\title{
In Search of a Sustainable Training Model for Educational Interpreting - Stellenbosch University: A Case Study
}

\author{
Prof Harold M Lesch \\ Associate Professor \\ Dept of Afrikaans and Dutch \\ Private Bag X1 \\ MATIELAND, 7602 \\ South Africa
}

\begin{abstract}
Interpreting in the tertiary classroom is of a mixed type and mode. Even though it is described as educational interpreting,it is 'primarily conference-type simultaneous-mode interpreting, but at times becomes liaison-type simultaneous-mode interpreting in interactive portions of the class' (De Kock\&Blaauw 2008:88). The various roles that are expected of the interpreter by the lecturer, student and the commissioner, as the initiator of the service, is demanding for the newcomer to the field. One should consequently guard against poorly recruited and trained educational interpreters and, ultimately, an inadequate service within the tertiary context, as it is highly critical (also towards the interpreting service). The nature of the context means that there is little room for trial and error, if any, in the face of highly critical academics or professionals-to-be. An adequate interpreting service should be installed, if not the interpreting service as a whole can be in jeopardise.
\end{abstract}

I am of the opinion that in order to enhance the interpreting service, sufficient emphasis should be placed on adequate training of the interpreters, balancing interpreting methodology, and practice. An academically sound training model groundedin research-based training (see Pöchhacker 2010: 2-4)for better equipped educational interpreters should be the foundation, i.e. training that is underpinned by justified academic principles and that exceeds the master-apprentice training model. This article is the first step in exploring this direction.

Keywords: interpreting, educational interpreting, training, experiential learning

\section{Introduction}

A multilingual language policy within higher education brings forth its own challenges for effective teaching and learning. Consequently; this may have an impact on the education environment and brings forth its own challenges to the learning experience. I am of the opinion that it is vital that studentson tertiary level should be able to further their academic studies to realise their full potential. It is generally accepted by educationalists that mother tongue education is still the most effective avenue to reach this objective.

One technique to assist inaddressing this challenge is the use of educational interpreters in the tertiary classroom. Educational interpreting ${ }^{1}$ has the potential to enhance both individual as well as institutionalmultilingualism. The underlying principle is that knowledge and learning should be accessed via more than one language. This is in accordance with Abediet al.(2004:6) who refers to assessments, i.e. when testing knowledge, and state thatdifficult resources that include in my opinion potential linguistic challenges should be removed that are irrelevant to the intent of themeasurement. In essence, language barriers during teaching and learning should also be removed. The language policy of Stellenbosch University (SU) views educational interpreting as an avenue to assist the institutional language policy. To enhance the latter, interpreting training services are at the university's disposal to assist with the implementation of the institutional policy of multilingualism.A potential problemin my opinion is that the existing training has certain shortcomings that may impact negatively on service delivery. These include, among others, the length of the training the educational interpreters undergo that will be taken-up as professionals to deliver the service and the limited interaction between interpreting methodology and practice.

\footnotetext{
${ }^{1}$ A distinction is drawn between sign language educational interpreting and oral language educational interpreting. The latter is the focus of this article and is defined "as simultaneous interpreting that is rendered by a professional interpreter who is present within the educational situation" (Verhoef and Du Plessis 2008:13). According to Kotzé (2014:129), there is enough evidence "to accept educational interpreting as a type of interpreting which is determined and governed by the social interaction within which it takes place, thereby solidifying educational interpreting as a type of community interpreting. 42
} 
In the process, research-based training (see Pöchhacker 2010: 2-4)i.e. training that is underpinned by justified academic principles and that exceeds the master-apprentice training model. As Stern (2011:340) puts it, ' $\ldots$ it is doubtful whether short courses are effective in imparting the necessary skills for novice interpreters,' even though Lotriet (2002:98) concluded that short interpreter training can definitely be effective. However, she is quick to add that follow-up contact and feedback are important and although training is done in simulated situations, the 'real situation has its own demands and problems' (Lotriet 2002:98).

Addressing theintercultural communication problems that arise during teaching and learning entails more than merely providing an interpreter to bridge the linguistic impasse. Interpreting is indeed a step in the right direction, but should be enhanced to render an academically sound service. In such a highly professional and critical context like anuniversity, one should guard against perpetuating the common interpreting practice errors and stepping into general pitfalls, consequently trying to reinvent the wheel.In securing an effective interpreting service, successful training and induction to the specific area of service delivery are key aspects for the novice interpreter. Research has shown that experiential learning is a powerful pedagogy, as it involves first-hand experience. For the novice to gain the most from the experiential learning activity it should be structured in such a way that it enhances student development. This cycle provides the trainee with the means to create a link between learning experiences, theoretical grounding of these experiences and the real world. Furthermore, experiential learning provides room for active experimentation that can transform conceptualisation, test abstraction in practice, and construct and modifythe next experience.Although this may take place under supervision, the activity should not be equated to the master-apprentice model; on the contrary, research-based teaching should form the basis for the training (see Pöchhacker2010:1).

Against the backdrop of Kolb's cycle (1984:41) for experiential learning, a sustainable model for training and experiential learning for educational interpreters is suggested. Practicum, service learning, and interacting with community groups reinforce the underlying understanding that students need to learn through interactive, collaborative experiences with others and foster the development of critical thinking, decision-making, and self-assessment (Winston, 2005:223).To aid this process, the aforementioned sustainable model becomes necessary. Establishing this model requires reflecting on the current state of educational interpreting training and the methodology involved in the marrying of the relevant theory and interpreting practice to justify the model concerned.The ultimate goal is to put forward an academically justified model for educational interpreting training within the SU context. The article is structured as follows: i) the language context will be provided as a rationale; ii) relevant theoretical aspects of interpreting are considered with the focus on quality and experiential learning; iii) the interpreting training model is outlined; and lastly iv) the modelis justified in relation to the performance of the interpreter.

\section{Language context}

The Language in Education Policy (1997) provides an overview of the objectives that one hope to achieve in terms of language in the educational context. The policy aimsto facilitate communication across boundaries of colour, language, and region, while at the same time encouraging a context where respect for languages in addition toone's own mother tongue is developed (Language in Education Policy 1997:1). According to Verhoef and Du Plessis (2008:7), the language policy of higher education is linked to the constitutional principles of multilingualism and the right to access to education. Despite the language policy and framework concerning a multilingual society, there is unfortunately still a challenge and hiatus between policy and the successfulimplementationthereof. Consequently, there is quite often a tension between policy and its implementation.

The major challenge regarding the language policy of universities is to align their own language policy with the national language policy and then to implement their policy successfully (Verhoef\&Du Plessis 2008:7). Stellenbosch University recently experienced an intense language debate,as there is an increase of students who do not have Afrikaans as their first language. Nonetheless, they wantaccess to SU while those already enrolled experience the predominantly Afrikaans context as limiting and hampering their learning and ultimately their academic success. This experience is communicated despite the claims that SU should be seen as a multilingual institution. Throughthis multilingual approach, institutional multilingualism, i.e. the use of more than one language by the institution, and individualmultilingualism, i.e. the use of more than one language by the individual,are advanced.

Inclusivity is enhanced,inter alia, by using Afrikaans and English in teaching. In the learning and teaching context, the two languages are used in different usage configurations, namely parallel medium (a class group is divided into two streams, one Afrikaans and one English); with real-time educational interpreting between Afrikaans and English, and dual medium (Afrikaans and English are used in the same class). With this mixed language model, SU wants to deliver graduates who understand the broader multilingual context and who are able to function within this multilingual context. 
What is quite clear is that educational interpreting is suggested as a viable option in the official documentation of the University. Moreover, there is a marked increase in the number of lectures that are interpreted ${ }^{2}$ and also in the appointment of educational interpreters. As educational interpreting plays such a major role and is included as an official language specification as determined by SU policy, one should secure an academically sound service. In such an academicallycritical context one should secure a quality educational interpreting service by suitably trained interpreters.

\section{Interpreting quality}

Even thoughMelby (2014)refers to translation, it also holds true for interpreting when hestates that there are certain quality-relatedexpectations. These include:

- Buyers of translation services need assurance that translations meet their quality requirements.

- Sellers of translation services need to have assurance that their translations will be acceptable.

- Users of translations need to have content that meets their needs and is fit for the purpose for which it is intended.

Against this backdrop, he offers the following definition for quality translation: 'A quality translation demonstrates required accuracy and fluency for the audience and purpose and complies with all specifications negotiated between the requester and provider, taking into account end-user needs' (Melby 2014).

The perception of providing a quality simultaneous interpreting service has been at the centre of debate and research for some time (see Kramer aus Bochum 2006). The concept of quality is, however, extremely slippery due to its subjective nature and it may certainly be regarded as multifaceted. According toMacíasPradas (2006:25), '[q]uality in interpreting has come to be viewed in relative rather than absolute terms'. Furthermore, quality in interpreting may be based solely on expectation (end-user and peer) or could be widened to include Pöchhacker's (2002: 97) notion of the user's cognitive grasp of the message delivered. This includes the assessment of variables such as speed, pauses, hesitations, intonation, fluency, obvious mistakes, register and style (Kahane 2000:6). Straniero (2003:135) believes that there is a 'gap between ideal (academic) quality and situated (real-world) quality'.

The notion of quality in interpreting therefore remains a field to be explored. According to Pöchhacker (2002:97), the most prominent criteria often considered for quality interpreting are accuracy, fidelity and clarity. These criteria are particularly product-based, but it is obvious that the product in itself is not the only factor to be considered. Pöchhacker (2002:97) is of the opinion that the criteria with reference to quality should relate to various areas of the communicative situation of interpreting. Factors such as the professional behaviour of the interpreter should coexist with the more theoretical issues such as ideational clarity, linguistic acceptability, terminological accuracy and fidelity (Gile 1995:34). One would, however, for the purpose of this article includetraining, qualifications, accreditation and working conditions, as they all must surely have an impact on the quality of delivery. To further this notion, Edwards, Temple and Alexander (2005:75) state that '[t]here is a growing emphasis on professionalization, with recognised training and qualifications for interpreters'.

This article does not deal with quality per se and does not provide answers to questionssuch as 'What is quality in interpreting?' or 'How should one measure quality in interpreting?' Instead, it takes its cue from work done by, among others, Moser-Mercer (2008), whichwould seem to indicate that different roleplayers in any particular interpreting scenario mayhave different definitions of 'quality', depending on their role in the process (Moser-Mercer2008:147).

As a backdrop to the proposed model,the context is taken from fourrelevant empirical studies conducted at SU, and the value of experiential learning, i.e. a strategy to integrate education and personal development, is also take into account.

\section{Relevant studies in Educational Interpreting at $S U^{3}$}

\subsection{Clausen's study (2011)}

This studyinvestigated the possibility of educational interpreting at SU, specifically in the University's Faculty of Arts and Social Sciences. It focused on the receptiveness toand thepotential of such a service as well as its logistic implications. In addition, the study explored thesuccess of using an interpreting service during lectures as well as the hindrances in doing so.

\footnotetext{
${ }^{2}$ In 2015, 365 lectureswere interpreted per week, whereas 113 lectures were interpreted per week in 2014.

${ }^{3}$ The author was involved in a more or lesser degree with three of these studies, namely that of Clausen (2011) and Brewis (2013) which were conducted under his supervision; and the SU Language Centre Study (2013) of which he was a member of the research team. 
The empirical part of the study involved an experiment in the first half of the first semester in 2010 inthe Department of Social Work in the Faculty of Arts and Social Sciences to determine whether itwould be feasible to use interpreting during lectures. A whisperedinterpreting service was renderedto interpretlectures on various occasions on second-year as well as third-year level.

The study found that it would indeed be possible to have an interpreting service during lectures.Although a few problems were highlighted, they were shown to be surmountable. The majority ofstudents who took part in the trial expressed a need for an interpreting service. One of the conclusions reached is that close cooperationbetween the interpreter and the lecturer is of fundamental importance because it creates a relationship oftrust, which in turn helps to ensure that the interpreting service is implemented successfully.

Apartfrom other practical issues regarding the size of the lecture hall, cooperation between the interpreters and the lecturers as well the importance of quality assurance, Clausen (2011:108-109) specifically refers to the experience of the interpreters as well as the possibility of an internship:

As discussed ... it would not be possible for the interpreter used during the trial to do her job well had it not been for the experience and training that she had at the start of the trial. The possibility exists, however, that the use of qualified and experienced interpreters in the classroom setting would not be cost-effective. If qualified and experienced interpreters seem to be too expensive, it can be considered to make use of students who undergo in-service training, as at the NWU (Blaauw, 2007: 6). In so doing, it will be ensured that interpreters have the necessary subject knowledge and terminology. In this way the interpreter also would not be seen as an outsider because he/she is a fellow student. By using in-service training students (instead of professional interpreters that charge professional fees), costs can be reduced and the implementation of the service would become more feasible. (Original in Afrikaans; translated by the author)

One has serious reservations about the use of student interpreters merely to cut costs within this academic context, is that it can result in negative unintended effects on the receivers (Chesterman 1998:222). However, onebelieves there is merit in Clausen's reference to service learningwithin the context of blended learning whereby the lay interpreter will gain relevant custom-made experience.

\subsection{Brewis'sstudy (2013)}

This study investigated educational interpreting with reference to contemporary ideas from academic literacy studies. Concepts such as affect, identity, accessibility and participation are investigated in order to describe possible relationships between educational interpreting and teaching and learning. The research was done against a discussion of concepts of interpreting theory, which include the role of the interpreter, quality of interpreting and professionalism. Over a period of four weeks, a trial in two modules in SU's Law Faculty was set up. The goal was to determine whether students understood the subject content better as a result of the interpreting and the following questions were considered: 'Do students identify better with the classroom situation because of the interpreting service?' and 'Does educationalinterpreting assist students with time management during the learning process?' Data wasgathered by way of action research and questionnaires, a focus group discussion, interviews and field observation (Brewis2013:94-103).

Brewis (2013:163-164)came among others to the following conclusion that is relevant to this article:

- Interpreting is very demanding and experience and skill play an important role.

- Interpreters should have the necessary experience and a good understanding of the discourse in the classroom aswellas the broader learning context.

Furthermore, Brewis (2013:153) concurs with Harrington (2000:94) who was working in the domain of educational Sign Language interpreting: "The ability to function effectively in these roles demands advanced knowledge and experience of not only the subject matter, but also the setting in which they are working. Someone who has never attended a college or university cannot be expected to understand the culture of such a setting". Harrington (2001:94) is further of the opinion that interpreters in the tertiary teaching context should at least be in possession of a university degree or should have at least personal experience within the context where interpreting takes place.

In the context of Brewis'sstudy, the interpreter should be familiar with the elements of classroom discourse and of legal texts, as Brewis'sinvestigation was done in the Law Faculty.Within the legal context, interpreters are expected to have knowledge and understanding of the degree of precision that is required in the systematic build-up of legal arguments and the principles of logical deliberation (Romero in Feinauer\&Lesch, 2011:5).

\subsection{Study by the SU Language Centre (2013)}

The study under the auspices of the SU Language Centre by De Stadler, L., Van Rensburg, A., Cilliers, I., Lesch, H., Foster, L. and Snyman, L. focused on a number of issues regarding the implementation of educational interpreting at SU. 
This extensive report consequently presents the results of a research project on the viability of educational interpreting on the campus. The project was conducted in a number of faculties in the course of the second semester of 2011. The project also benefitted from insights from an extensive literature survey and visits by members of the research team to two universities where educational interpreting was already in place.

The Language Centre (2013: 52) came, among others, to the following conclusion that is relevant to this paper:

That in the planning of the educational interpreting system, account should especially be taken of the availability of interpreters, the willingness of interpreters to interpret within an educational setting, the training of the interpreters and the system that is needed to manage a large amount interpreters for a variety of modules on a daily basis. (original in Afrikaans; translated by author)

\subsection{Booysen'sstudy (2015)}

Booysen (2015: 41) made the following remark regarding the training of newcomers:

Once they[the trainee interpreters] are comfortable with shadowing, the audio levels are adjusted so that the lecturer's voice is raised above that of the interpreter. Now, trainee interpreters must actually interpret what the lecturer is saying into the target language. At first, the recording is whisper interpreted by all the trainees, but later on, one interpreter will interpret while the rest of the team listens through the headsets. This provides the trainees with some hands-on experience with the interpreting equipment. After every trainee interpreter's turn, other trainees and more experienced interpreters take a few minutes to do a peer evaluation of the interpreting product. They point out what was good, what needs improvement, what the interpreter should focus on, and where possible, they make suggestions and share experiences of similar issues. By the end of the two weeks, trainee interpreters who might have no previous educational interpreting experience should have a good idea of what to expect when interpreting a lecture.

With reference to the above studies, training formsan important part of successful interpreting implementation, but one is of the opinion that more direct experience during training should be providedas opposed to the two weeks as indicatedby Brewis and that knowledge of and insight into the relevant interpreting methodology should be gained. To contextualise the notion concerning direct experience and to enhance research-based training, the notion and value of experiential learning should be utilised.

\section{Experiential learning and proposed model}

Experiential learning for interpreter training should be contextualised within the framework of blended learning. Blended learning refers not only to the delivery modality (...)but to a whole set of didactic concepts such as self-paced and collaborative learning, structured and unstructured learning, custom and off-the-shelf content, supplementing learning with practice and just-in-timeperformance (Class, Moser-Mercer \&Seeber 2004:510).

Regardless of the refinements and applications of an experiential learning theory, the model of David A. Kolb (1976; 1981; 1984) and his associate Roger Fry (Kolb\&Fry 1975) remains a central reference point for discussion. Building on the ideas of Piaget, Dewey and Lewin (1951), Kolb and Fry (1975) explore the processes associated with learning from experience. They regard experiential learning as a strategy integrating education, personal development and work (HEQC 2006:17). See also Lesch (2011 and 2014) regarding the role of service learning forinterpreter training. 
Immediate

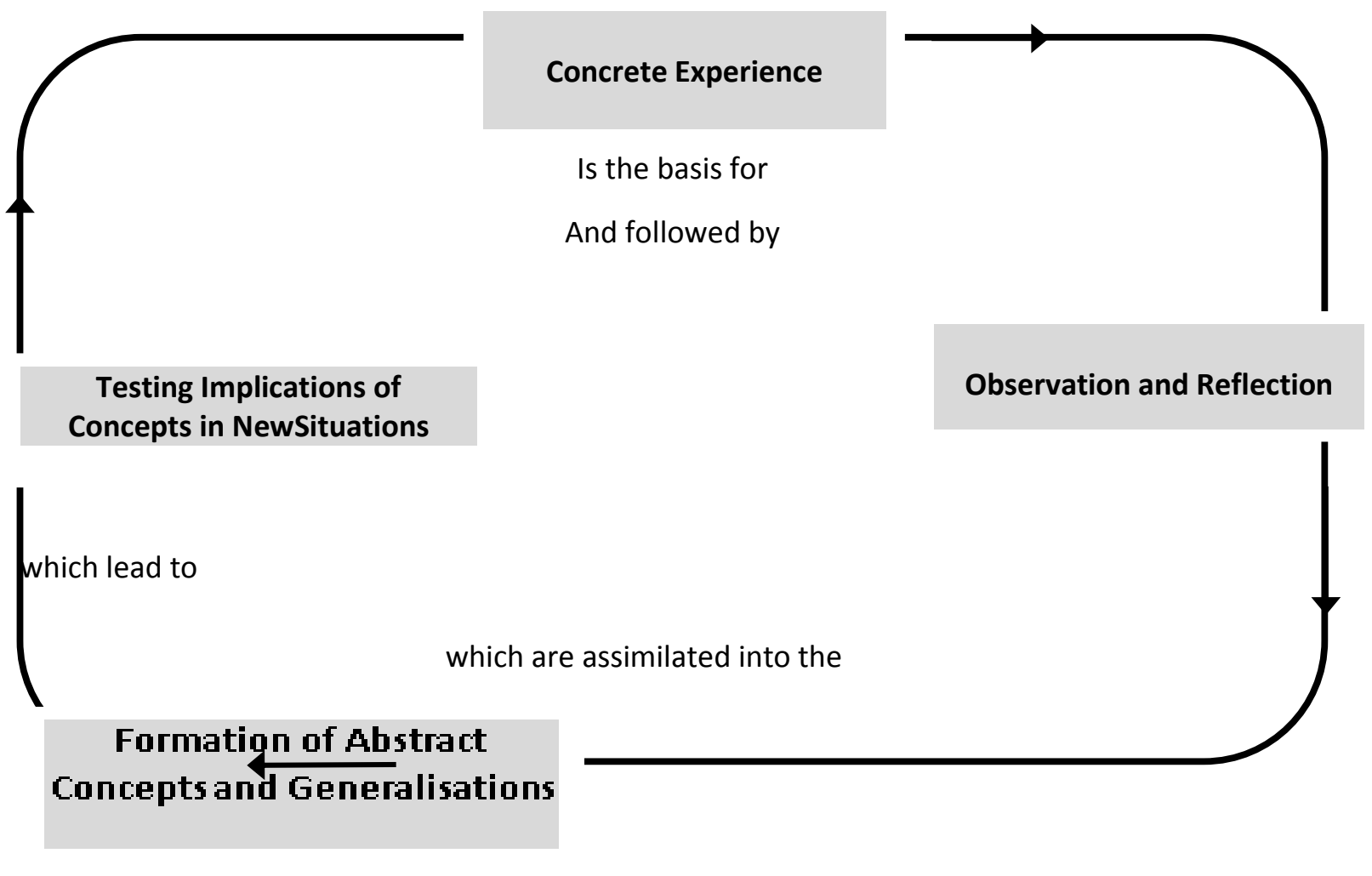

from which implications for action are deduced

Graph 1:Kolb's (1984:41) Experiential learning cycle (redrawn)

Kolb's concept of experiential learning (as is the case of the trainee interpreter) further explores the critical pattern of all learning from experience through reflection to conceptualisation and action, returning to further experience. Concrete experience entails direct practical experience. Witter-Merithew and Johnson discovered that when apprentices work together to reflect on their work, they 'gain deeper levels of understanding' (2005:45). Reflective observation focuses on what the experience means to the individual and requires observation, examination, analysis and interpretation of a specific concrete experience. Abstract conceptualisation gives meaning to discoveries by relating them to other discoveries, i.e. other forms of knowledge, and active experimentation is taking further action and testing conceptualisations (and their implications) in different situations. Research has shown that experiential learning is a powerful pedagogy that involves expertise. For students to optimally benefit from the exercise, it should be structured so that it enhances student development. This cycle offers the student with the means to create a link between learning experiences, theoretical grounding of these experiences and the real world. Furthermore, the cycle provides room for active experimentation that can transform conceptualisation, test abstraction in practice, and construct and modify the next concrete experience. According to Sax and Astin (1997), the outcomes of service learning are aimed at academic development and life skills, including racial tolerance and cultural understanding (especially in intercultural communication).

As language is so often taken for granted, it is important that one should decide on a language community interaction activity that shows that it has an impact on the community, but most importantly also adds value to training purposes from the perspective of the interpreter. The community should be involved in the evaluation of the trainees- however, this can be problematic for a highly skilled activity as interpreting). ${ }^{4}$ The students should also build on their experience and it is important that they share it with the rest of the group.

\footnotetext{
${ }^{4}$ What one has discovered in a preliminary survey is that the novice community of interaction will in their evaluation of the trainee give higher scores for their interpreting skills than a seasoned language practitioner. Even though language use is a daily activity, interpreting is a highly skilled activity and it can be problematic for the novice to evaluate the interpreting skills.
} 
However, to train these beginner professionals, exposure to and experience in the profession become important even though the practice is to a certain extent still in its infancy. Winston in Bentley-Sassaman (2009:66) states that 'practicum, service learning, and interacting with community groups all reinforce the underlying understanding that students need $[\ldots]$ to learn through interactive, collaborative experiences with others' (Winston 2005:223). Winston goes on to say that the aforementioned activities are 'student-centered learning activities that foster the development of critical thinking, decision making, and self-assessment that are essential to interpreting effectively and competently' (ibid.). Critical thinking, ethical decision-making, and self-assessment are key factors deemed necessary characteristics for students to possess as they enter the field of interpreting. According to community interaction principles, experiential learning should not be seen as an indiscriminate activity where students have carte blanche, but it should be embedded within a credit-bearing course. Students must reflect on the service activity in such a way that they gain further understanding and broader appreciation of the discipline and develop a sense of personal values and civic responsibility (Bringle\&Hatcher 1995:12). Apart from the functional linguistic skills that students achieve with their community interaction, issues of ethics also come into play.

Against the backdrop (see Kolb's cycle again) one is aware of the pedagogical advantages experiential learning holds for the trainee interpreter.

\section{Training model for educational interpreting ${ }^{5}$}

The point of departure is that interpreting is an extremely specialised, complex and experience-based professional skill. Some people have a natural talent for it, others need to be to be taught. It is, however, a skill which can be sharpened, provided that the prospective interpreter is naturally attuned to it. Unfortunately, there are those who simply cannot make the grade as interpreters - the pressure and intensity of the language skill proficiency are simply too much for them.As the recruiting and screening of candidates to be trained is a preliminary process and not the emphasis of this article, it suffices to stay that an aptitude test as a predictor or forecaster (Russo 2011:6) will be used to distinguish between those applicants who are deemed to have the potential to become interpreters and those who are not. However, it is in itself difficult to select the appropriate tests that will provide the necessary information which trainers need in order to determine this potential (Timarova\&Ungoed-Thomas 2008:29-30).See also Gambrell (2018) regaring aptitude testing.

In an academically sound interpreting training model with a number of properly trained and tested interpreters as an outcome, various aspects of the field should be covered. This should include an intensive study of the methodology of interpreting along with independent reading and a considerable component involving practical exercise. Interpreting is only effective, in the full sense of the word, when the interpreter can thoroughly situate himself within the context of the academic environment while considering the history of (educational) interpreting.

The proposed model comprises an initial three-week contact session that will cover, among others, the following:

Week 1: Methodology and introductory exposure to the practice of interpreting

The first week of the training model includes the following aspects:

- The contextualisation of interpreting as practice, in generaland specific to SU, with reference to the language policy of SU, as well as the synergy of interpreting, education and learning.

- Academic literature studies on educational interpreting: lectures and discussions.

- Academic literature studies on classroom interpreting: presentations by studentinterpreters and discussions.

- Educational interpreting as an example and branch of simultaneous interpreting: differences and similarities. (The interpreters should understand that the key difference between educational interpreting and other forms of simultaneous interpreting resides, in the first place, in the relationship students build with their lecturer in the class. In the second place, the educational interpreter plays a unique role, as the interpreter is in this case more than just a conduit but applies a form of community interpreting in the simultaneous mode.

- A discussion on etiquette, professionalism and technical skills with demonstrations of and exposure to equipment.

This is done by setting the context regarding language planning and implementation and its relevance to SU; interpreting as an aid in facilitating the SU language policy; interpreting in the recent past; the challenges of interpreting; andthe placing of educational interpreting within the interpreting typology. An academic literature review of educational interpreting will follow where relevant studies will be discussed. Aspects that will be covered hereinclude: management of processing capacity; various modelsand the code of conduct;educational interpreting practice and the classroom situation; etiquette; professionalism; and technical skills with demonstrations and exposure to equipment.

${ }^{5}$ This training model has been devised with the input of colleagues concerned with translation and interpreting in the Department of Afrikaans and Dutch, Stellenbosch University. 
The practical sessions will include appropriate exercise including thefollowing:voice production; shadowing; attentionsplitting; memory exercises; and impromptu exercises.Furthermore, generic and educational interpreting skillswill be enhanced, including simulated classroom situations for interpreting exercises.

Week 2: Practical

This component involves five days of intensive interpreting during which the trainers offer continuous feedback in support of development and improvement. The interpreting methodology covered during the first week is continuously linked to the practical exercises. This component focuses on generic interpreting skills and the unique demands of educational interpreting, specifically with reference to the relationship between the interpreter and the lecturer in a particular module. This also takes into account the additional tasks, apart from interpreting, which the interpreter should perform. The technique for educational interpreting does not really differ from 'normal' simultaneous interpreting, but the situation in which the educational interpreter works poses unique challenges which will be dealt with during the practical training. Thus, taking notes and compiling terminology lists are indirect skills that are almost as important as being able to interpret in the lecture hall. The potential practical problems concerning aninterpreting service should also be discussed. These include where the interpreter should sit in the venue and how to proceed if the lecturer needs support in making as much use of the interpreter as possible within the lecture hall.

The main features of the week include the following:

- Simulated lectures which are interpreted.

- The handling of the educational context.

- Liaison between educational interpreters and lecturers during the lectures.

- Preliminary assessment of interpreters at the end of this week by means of assessment instrument.

- Feedback to students.

After this week of training, the prospective interpreters are placed to shadow practicing educational interpretersand are monitored by qualified interpreters.Following this initial training, one suggests that the prospective interpreters should receive 30 hours of practical exposure as shadow interpreters and assistant interpreters, after which they receive the opportunity for rounding off, problem discussion, and final assessment during a final session (which, once again, extends over a week).

Week 3: Final assessment and (self-) evaluation

During the last week of training, the prospective interpreter gains the necessary exposure to the context and the interpreting practice. At this stage, intensive practical interpreting is done which is evaluated by the lecturers and the other prospective interpreters. This week of the training follows after the prospective interpreters spent a prescribed 30 hours practising educational interpreting and were monitored by educational interpreters. The third week's training need not necessarily follow directly after the first two weeks and it is possible to complete 30 hours of practical exercise before the third week of training takes place. The third week can, however, also follow directly after the first two weeks. In the third week of training, the following aspects occur:

- Intensive practical interpreting.

- Evaluation by the trainers, but student interpreters also provide input on one another's interpreting work.

- Assessment by means of the in-house instrument which was developed.

At the end of the full, three-week training programme, the candidates are formally evaluated. Those who pass receive a validation of their training, most likely in the form of a proficiency certificate. Students who are not successful should also receive detailed feedback on, among other things, whether there is a possibility for them to improve their skills. The final evaluation will take place on the basis of existing and trusted assessment criteria, which will also take into account the realities of the unique context of educational interpreting. The final assessment is done by qualified experts who have theoretical and practical knowledge and are themselves experienced interpreters.

\section{Relatingthe training model to theory}

The proposed training model, as stated above, should be valued against the backdrop of the various levels of interpreting expertise: beginner to intermediate to advanced interpreter. It is through this blended learning, including first-hand internship experience that the novice interpreter will experience Niska's (2002:137-138) role pyramid. Even though the educational interpreter spends most of his duty fulfilling the role of a conduitin certain cases, it is essential to change within the pyramid ofpossible roles, subjectto the situation (Verhoef\&Blaauw2009:210-211). When performing a conduit role, only language information as offered in the source text is being relayed. However, in certain instances, it may be necessary to provide more information to ensure that the target text message is intelligible and to provide effective communication. 
In such an instance, the interpreter takes on the responsibility to clarify.At the most advancedlevel, the interpreter advocates for the userin the education context, the student. This is the most involved and advanced role and is the role which the interpreter plays for a very short time. The underlying principle of Niska's (2002) model is that the interpreter (also the educational interpreter) fulfils various responsibilities at the same time. Kotze (2014:135) states thatthe educational interpreter is no longer bound to only one role and may choose which role is more appropriate in a specific setting. The reality is that the educational interpreter is not an invisible conduit, but is directly part of the conversation.

The interpreting methodology and theory that the students gain during week one are complemented by genre-specific exercises in week two with the blended learning activities that follow. This is then completed within a semester of hands--on experience. The proposed training model aims to strike a balance between theory and practice, as the interpreter is seen as a professional individual. This hands-on training will equip the interpreter to perform with greater confidence in a highly professional and critical context.As a professional, the interpreter will gain the necessary theoretical knowledge and practical know-how. The dialectical relationship between theory and practice will be foregrounded in this manner. In short, the performance of the interpreter will be substantiated by his competence:

The professional competence, as a set of conceptual knowledge,procedures and attitudes, is that which allows one (the interpreter)to resolve problems autonomouslyand flexibly, when realizing a task individually as well as when coordinatingwork within an organization (Dirube 2004:70).

According to KuznikandAlbir (2015:4-5),there is not necessarily an oppositionbetween 'competence'and 'performance', but is rather aneffortto build an relation between the competence (that is an underlying entity, andcomposed of attitudes, traits, knowledge, motivation, etc.) and how it is expressed(the behaviour). The liaison between the various components of competence and their counterparts is often signified in the form of an iceberg. This idea of an iceberg clarifies how the notion of competence focuses on the existing causal relationship between competences (i.e. underlying entities which include among others competence, aptitude and abilities, personality traits, aptitudes and values, knowledge, and motivation), which cannot be observed directly, and behaviour which can be observed.These competences are understood as 'the characteristics of certainpeople which mean that their behaviour is particularly satisfactory in the businessor organization environment in which they are developed. As [...] manifestedthrough behaviour, competences are a compendium of knowledge, skills, habits and motivation' (Dirube 2004:98). Competence is seen as the cause of performing entrusted tasks in the workplace, i.e. educational interpreting context, to satisfaction.

The closerelationship between competences and how they are expressed in observablereal-life situations mean that they are models designed to be applied.I would thus agreethat this also applies to educational interpreting and that there is a dialectical relationshipbetween the competence of the educational interpreter and their performance.

\section{Conclusion}

This article set out to offera sustainable model for the training of educational interpreters. At the basis of this model lies the premise of meaningfulsynergy between research-based training and service delivery. The various roles that the educational interpreter has to fulfil also justify the need for experiential learningas suggested in the proposed model. One wants to concur with the viewpoint that'educational interpreting is not merely about placing interpreters in classrooms, but that managing and marrying expectations - whether presumed or actual - could have an important influence on the perceived success of such a service'(Foster 2014:88). The underlying principle is that knowledge teaching and learning should be accessed via a quality interpreting service. The intervention of putting an interpreting service in place should not itself result in unintended negative effects due to poor training and consequently a poor service that is being delivered.

\section{Bibliography}

Abedi,J., Hofstetter, C.H. \&Lord, C., 2004, 'Assessment Accommodations for English learners: Implications for policybased empirical research', Review of Educational Research 74(1) 1-28.

Bentley-Sassaman, J., 2009, 'The Experiential Learning Theory and Interpreter Education', International Journal of Interpreter Education, Conference of Interpreter Trainer: 60-67.

Beukes, A., 2008, 'Language policy implementation in South Africa: How Kempton Park's great expectations are dashed in Tshwane', Stellenbosch Papers in Linguistics, 38, 1-26, viewed 11 September 2014, from http://sun025.sun.ac.za/portal/page/portal/Arts/Departments/linguistics/documents/SPIL38-Beukes.pdf 2.

Blaauw, J., 2007, 'Recruitment and training to source interpreters for educational interpreting', Muratho, October, 5-8. 
Booysen, L., 2015, Educational interpreting in undergraduate courses at a tertiary institution: Perceptions of students, lecturers and interpreters, Master's thesis, Department of General Linguistics, Stellenbosch University.

Bringle, R.G. \&Hatcher, J.A., 1995, 'A Service-learning Curriculum for Faculty', MichiganJournal for Higher Education 2(1), 112-122.

Brewis, C., 2013,Die bevorderlikheid van opvoedkundige tolking vir effektiewe onderrig en leer binne die konteks van die Fakulteit Regsgeleerdheid aan die Universiteit Stellenbosch,Master's in Philosophy, Dept. of Afrikaans and Dutch, Stellenbosch University, viewed 10 September 2014, from http://hdl.handle.net/10019.1/80287.

Chesterman, A., 1998, 'Causes, Translations, Effects', Target 10(2).

Class, B., Moser-Mecer, B.\&Seeber, K., 2004, 'Blended learning fortraining interpreter trainers,Proceedings of the 3rd European Conference on E-Learning,Paris, November 25-26, 2004, pp.507-515.

Clausen, M.,2011,Die potensiaal van tolking in die Fakulteit Lettere en Sosiale Wetenskappe (US): Die Departement Maatskaplike Werk as Gevallestudie. Master's in Philosophy, Dept. of Afrikaans and Dutch, Stellenbosch University, viewed 10 September 2014, from http://hdl.handle.net/10019.1/80287.

De Kock, E.\&Blaauw, J.,2008, 'Are longer turns than the norm possible within an educational interpreting environment?'in M. Verhoef\&T. du Plessis (eds.), In: Verhoef, M. \& Du Plessis, T. (eds.) Multilingualism and Educational Interpreting - innovation and delivery. Pretoria: Van Schaik. pp. 82 - 98.

Department of Basic Education, 1997, Language in education policy, viewed 10 September 2014, from http://www.education.gov.za/LinkClick.aspx?fileticket=XpJ7gz4rPT0\%3D\&tabid=390\&mid=1125.

De Stadler, L., Van Rensburg, A., Cilliers, I., Lesch, H., Foster, L. and Snyman, L. The Language Centre, 2013, Die implementering van Opvoedkunidge tolking aan die Universiteit Stellenbosch, Report, The Language Centre, Stellenbosch University, Stellenbosch.

Dirube, M. J., 2004, Unmodelo de gestiónporcompetencias. Leccionesaprendidas, Barcelona, Gesión 2000/EPISE/Training Club.

Edwards, R., Temple, B. \&Alexander, C., 2005, 'Users' experiences of interpreters: The critical role of trust',Interpreting 7(1), 77-95.

Foster, L., 2014, Quality-assessment expectations and quality-assessment reality in educational interpreting: An exploratory case study', Stellenbosch Papers in Linguistics Plus43, 87-102, doi: 10.5842/43-0-207.

Feinauer, I. \&Lesch H.M., 2013, 'Health workers: idealistic expectations versus interpreters'Competence',Perspectives: Studies in Translatology 21(1), 117-132, doi:10.1080/0907676X.2011.634013.

Gambrell, S., 2018, Crafting an Effective Test: Devising a Model of Aptitude Testing for Interpreter TrainingMasters thesis Department of Afrikaans and Dutch, Stellenbosch University, viewed 13 July 2019 http://scholar.sun.ac.za/handle/10019.1/103322

Gile, D., 1995, Basic Concepts and Models for Interpreter and Translator Training,John Benjamins Publishing, Amsterdam.

Harrington, F.J., 2001, 'The rise, fall and re-invention of the communicator: Re-defining roles and responsibilities in educational interpreting', in F.J. Harrington \& G. Turner (eds.), Interpreting: Studies and reflections on sign language interpreting, Douglas McLean, Coleford/Gloucestershire.

HEQC, 2006, Service Learning in the Curriculum, a Source for Higher Education Institutions, JET Education Services and Council on Higher Education, Pretoria.

Kahane, E., 2000, 'Thoughts on the quality of interpretation', Communicate 4, viewed 14 September 2014, fromhttp://www.aiic.net/ViewPage.cfm/page197.htm, accessed on 26-11-06.

Kolb, David A., 1976, The Learning Inventory: Technical Manual,McBer and Co.,Boston.

Kolb, D. A., 1981, 'Learning Styles and Disciplinary Differences', in A.W. Chickering (ed.),The Modern American College, pp.233-255, Jossey-Bass, San Francisco.

Kolb, D.A., 1984, Experiential Learning. Experience as the Source of Learning andDevelopment,Prentice Hall,Englewood Cliffs.

Kolb, D.A. \&Fry, R., 1975, 'Towards an Applied Theory of Experiential Learning', in C. Cooper (ed.), Theories of Group Processes,pp. 33-58, Wiley, London.

Kotzé, H., 2014, 'Educational interpreting: A dynamic role model', inStellenbosch Papers in Linguistics Plus, 43, 127145,doi: 10.5842/43-0-147.

Kramer aus Bochum,A., 2006, 'Defining the elusive - interpreting quality research andits pragmatic relevance', Master's thesis, Institutfür Translation undMehrsprachige Kommunikation (ITMK), Fachhochschule Köln.

Kuznik, A. \&Albir, A.H., 2015, 'How to define good professional translators and interpreters: Applying the behavioural approach to study competences in the field of translation studies', Across Languages and Cultures 16(1), 1-27, doi: 10.1556/084.2015.16.1.1 1585-1923/. 
Moser-Mecer, B., 2008, 'Constructing Quality', inG, Hansen, A. Chesterman \& H. Gerzymisch-Arbogast (eds.), Efforts and Models in Interpreting and Translation Research: A tribute to Daniel Gile, John Benjamins Publishing, Amsterdam/Philadelphia.

Lesch, H.M., 2014, 'Die waardeenuitdagings van diensleervirtolkopleiding: die ervaring van die tolkopleidingsprogramaan die Universiteit Stellenbosch' in Stellenbosch Papers in Linguistics Plus, Vol. 43, 2014, 209-233 doi: 10.5842/43-0-201 http://spilplus.journals.ac.za

Lesch, H.M., 2011, 'The value and challenges of Service Learning for Interpreter Training:A South African perspective' In Modelling the field of Community Interpreting, Questions of methodology in research and training Edited by Kainz, C, Prunc, E and Schogler, ISBN 9783-643- 50177-6, pp. 213-241

Lotriet, A., 2002, 'Can short interpreter training be effective? The South African Truth and Reconciliation Commission experience', in E. Hung (ed.), Teaching Translation and Interpreting 4: Building Bridges, pp. 83-98. John Benjamins Publishing, Amsterdam.

Melby, A., 2014, 'Multidimensional Quality Metrics (MQM) Overview', paper presentedat the ICCT, Melbourne.

Niska, H., 2002, 'Community interpreter training: past, present, future', in G. Garzone\&M.Viezzi (eds.), Interpreting in the 21st Century. Challenges and Opportunities, pp.133-144, John Benjamins Publishing, Amsterdam/Philadelphia.

Russo, M., 2011, Aptitude testing over the years. Interpreting, 13(1):5-30.

Pradas, M., 2006, 'Probing quality criteria in simultaneous interpreting: The role ofsilent pauses in fluency', Interpreting 8(1), 25-43.

Pöchhacker, F., 2002, 'Researching Interpreting Quality: Models and Methods', in G. Garzone and M. Viessi (eds.), Interpreting in the 21st Century. Challenges and Opportunities, pp.95-106, John Benjamins Publishing, Amsterdam/Philadelphia.

Pöchhacker, F., 2010, 'The role of research in interpreter education', Translation\& Interpreting, 2(1), 1-10.

Timarova, S. \&Ungoed-Thomas, H., 2005,'The Predictive Value of Admission Testing for Interpreting Courses', in Continuing Education for Interpreter Trainers. Geneva: Université de Genève: 2-37.

Saulse, B., 2010,Interpreting within the Western Cape health care sector: A descriptive Overview,Master's thesis, Department of Afrikaans and Dutch, Stellenbosch University.

Sax, L.J. \&Astin, A.W., 1997, 'The Benefits of Service: Evidence from Undergraduates',Educational Record, 78, 2533.

Schlemmer, L., 2008,Voorgraadse Studente op die Universiteit van Stellenbosch en die Taalbeleid: ' $n$ Strategiese Meningsopname,Stellenbosch University.

Stern, L., 2011, 'Courtroom interpreting', in K. Malmkjaer\& K. Windle(eds.), The Oxford Handbook of Translation Studies, pp. 325-342. Oxford University Press, Oxford.

Straniero, S. F., 2003, 'Norms and quality in media interpreting: the case of formula one press conferences', The Interpreters' Newsletter, 12, 135-174.

Verhoef, M., 2006, 'Tolking as afleweringsmodus in universiteitsklasse? 'n Bespreking en analise van die Dagbreektrusttolkprojek aan die Potchefstroomkampus van die Noordwes-Universiteit', Tydskrif vir Geesteswetenskappe, Supplement: Moedertaalonderrig, 46(2), 89-99.

Verhoef, M., 2010,Taalbeleid en onderrigtaalmodus aan die Noordwes-universiteit.'n Studie oor Afrikaans op Universiteitsvlak,FW de Klerk Foundation,Plattekloof.

Verhoef, M. and Blaauw, J.,2009, 'Towards comprehending Spoken Language Educational Interpreting as rendered at a South African University in Continuum Studies on Translation', in J.Inggs \& L. Meintjes (eds.), London/New York: Continuum. pp. 204-222.

Verhoef, M. \&Du Plessis, T. (eds.), 2008, Multilingualism and educational interpreting: Innovation and delivery. Van Schaik, Pretoria.

Winston, E. A., 2005,'Designing a Curriculum for American Sign Language/EnglishInterpreting Educators', in M. Marschark, R. Peterson \&E.A. Winston (eds.),Interpreting and Interpreting Education: Directions for Research and Practice, pp. 208-234, Oxford University Press, New York.

Witter-Merithew, A. \&Johnson, L. J., 2005, Toward Competent Practice: Conversations with Stakeholders. Registry of Interpreters for the Deaf Press, Alexandria. 